SHS Web of Conferences 12,010 87 (2014)

DOI: $10.1051 /$ shsconf/ 20141201087

(C) Owned by the authors, published by EDP Sciences, 2014

\title{
Entrepreneurship as a Catalyst for Rural Tourism Development
}

\author{
Norhafiza Md Sharif $^{1}, \mathrm{Ku}$ Azam Tuan Lonik ${ }^{2}$ \\ ${ }^{1,2}$ School of Distance Education, Universiti Sains Malaysia, 11800, Penang, Malaysia
}

\begin{abstract}
The tourism industry is seen as capable of being an agent of change in the landscape of economic, social and environment of a tourist destination. Tourism activity has also generated employment and entrepreneurship opportunities to the local community as well as using available resources as tourist attractions. The tourism sector has the potential to be a catalyst for the development of entrepreneurship and small business performance. Through the development of tourism, the rural community has the opportunity to offer services or sell products to the both local and foreign tourists. To fulfill this purpose, local community participation in entrepreneurship is very important in order to develope the economic potential and to determine the direction of a development in rural areas. In the context of entrepreneurship, local participation is important not only as an entrepreneur and labor in this sector as well as complementary sectors of the others, but they can serve to encourage the involvement of other residents to join together to develop this entrepreneurial. This article aims to discuss the extent of entrepreneurship as a catalyst to the development of tourism in rural areas. Through active participation among community members, rural entrepreneurship will hopefully move towards prosperity and success of rural development.
\end{abstract}

\section{Introduction}

The tourism industry has been identified as one of the leading industries to drive development and economic transformation in developing countries [1]. In Malaysia, tourism is the second largest contributor to the economy after manufacturing sector. The sector is also one of the 12 National Key Economic Areas under the Economic Transformation Programme. In the Eighth Malaysia Plan (20012005), the tourism industry has experienced impressive growth where it contributes to foreign exchange contributing to economic growth, investment and employment opportunities as well as strengthening the services account of the balance of payments. Identifies five key benefits to be derived from the development of the tourism industry namely the contribution to the balance of payments, the non-industrial development, new job opportunities, increase revenues to the economy through the impact multiplier and social development. It is also argued that the sector could reduce unemployment by creating new jobs [2]. [3]also see the sector could reduce unemployment by creating new jobs [2].

Currently, Malaysia is ranked 16th in terms of global tourism receipts, which is being estimated at about $2 \%$ of global market share in 2008 providing opportunities for 1.7 million jobs, or about $16 \%$ of total employment in 2008 (The Tenth Malaysia Plan, 2006-2010). Therefore, tourism activities are 
seen as capable to create employment opportunities to the rural communities. For example in 2009, a total of 204,000 people or $5 \%$ of the rural population engaged in the hotel and restaurant sector, compared with $2.2 \%$ of labor force participation, or 74,000 people in the fisheries sector [4].

This helps rural tourism to be recognized as an effective catalyst in the socio-economic development in many rural areas. The increase in rural tourism development is due to the increased demand from tourists who want to enjoy nature found only in rural environments as well as to experience cultural heritage that is still preserved by the rural communities [5]. All these lead to the growth of the nature based tourism (eco-tourism), agro tourism and homestay. According to [6], the homestay program, for example, encourages rural communities to participate in the tourism industry, increase their income and create tourism entrepreneurs in the rural areas. The increasing demand for tourism products will indirectly encourage new investments in infrastructure, communications and transport [7] and develop rural areas through other social support.

According to [8], the resilience of this sector is the result of the active participation of the public and private sectors in promoting and enhancing the competitiveness of tourism products that attract tourists to visit Malaysia. Continuous efforts are made towards realizing the potential of the rural tourism sector to increase its contribution to the service sector in particular and the economy as a whole. Facilities provided by the government helps to improve the performance of the tourism industry [9]. In order to ensure the sustainability of the sector, the government is moving one step forward with the creation of the Master Plan for Rural Development (2010) as a key policy in support of rural development policies and national programs and outlines strategies for comprehensive development of rural areas until 2020. It will be a general guideline to all the parties involved in the rural development activities, including government agencies, private sector, NGOs and others.

Nonetheless, in the context of rural tourism development, questions that are often being raised are whether the local rural communities are being marginalized by development projects in their areas without them involving in its planning. If that is so, the development of the tourism sector will be less effective in the absence of a balanced emphasis on human resource development of the local rural communities which are a vital component of the tourism industry. In terms of entrepreneurship, the local entrepreneurs often face problems in business because they could not compete with many other entrepreneurs due to certain reasons. This article aims to discuss the extent the local rural tourism entrepreneurs acts as catalyst to the development of tourism sector in the rural areas. Through active participation among community members, rural entrepreneurship will hopefully move towards prosperity and success of rural development.

\section{Rural Development}

The countryside is an area other than an urban area. It is a settlement that covers all types of villages and small settlements of less than 10,000 people and is characterized by areas of agriculture and natural resource areas. According to [5], communities in rural areas still do the job traditionally which are based on farming and livestock activities mainly subsistence.

The rural areas are often associated with areas of life that are not advanced, low level of education, community involvement is limited, the potential suspicious and various other characteristics backwardness. Thus, [10] states that the rural communities are often depicted as a group of community that are frozen, slow and lack the initiatives to advance. [11] adds that rural areas are synonymous with the area that are well behind in much of the modern amenities such as the lack of infrastructure, location of shopping facilities and new technologies such as internet access and a mobile communication device.

Constrained by the characteristics of the isolated and backwardness, rural areas have limited options for economic development. To stimulate the economic development of rural communities, rural communities must find alternative use of existing resources to improve their living standards [12]. Hence, the rural areas have the potential to be developed as a tourist attraction and to generate economic growth. 
Rural development is crucial to provide an effective delivery system that are beneficial to the local community as well as to develop a sustainable rural economy through the diversification of the economy, particularly relating to the tourism sector $[13,14]$. Efficient planning of rural development is capable to activate the involvement of the local communities in programs and projects in rural areas. Such as by enhancing their training that provide opportunities to generate income to the community, especially the youth [9]. Recent planning in rural development emphasizes empowerment of rural communities [15], which enable it to be dynamic and resilient, and are able to face the challenges of the future and achieve economic status equivalent to a national level.

\section{Concepts of Rural Community Participation}

Local participation is an important aspect in the development of tourism [16]. According to [17], community participation is about empowering local people to determine their own goals and in consultation with local residents to determine their hopes and fears for the development of tourism in their area. In the development plan, it is important to ensure that economic development have a huge impact on the local community occupational structure $[18,19]$. Analyze the employment patterns of society in Pulau Dayang Bunting, Langkawi by focusing on the level of labor participation and unemployment problems, the structure and type of employment and their implications on the level of income of the community. Community involvement in tourism is crucial to the development and sustainability of the economy in the affected areas [20].

As stated in the tourism charter of Asia Pacific Economic Cooperation (2010), Community Based Tourism (CBT) should be able to create jobs and to increase incomes and reduce poverty in rural areas $[21,22]$. In addition, community involvement is able to educate local communities about tourism [16,18,20,23] and raise their living standards [24]. [25] added that the development of rural tourism brings benefits in rural areas such as reducing the migration of the local population, providing vocational training, eradicating gender discrimination and other social categories, improving the social and cultural coexistence, providing opportunities for social interaction, and involving local population in decision making [26, 27] as well as promote the arts and crafts practiced by the community [25]. [28] also stressed that local community involvement in tourism sector can provide opportunities for them to improve their economics well-being and quality of life through the opportunities arising from the development of tourism activities such as in transportation, accommodation, handicrafts and so on. According to him, the involvement of local communities in tourism activities can be viewed from two perspectives, namely:

1. Involvement of local communities in decision making whereby through the participation of the local community, there exist an opportunity for them to express their hopes and desires to develop the area.

2. Sharing of the profit or benefit as a result of tourism activities that provide opportunities for the community to improve the economy and standard of living.

This perspective is also supported by Akama and [20]. They also urged that the local community be given the chance to recommend or prescribe a tourism development programs appropriate to their environment. To achieve sustainable tourism development, local residents should also take an active part in the transformation process because they serve as advocates to the prosperity and development of the tourism industry as well as serve as a workforce that will provide economic returns in the sector and the complement of the other. This is because the community is not only acting as a catalyst to tourism activities, but they are a crucial asset that can empower tourism activities more robust and efficient.

According to Arnstein, in the context of tourism planning, community participation is a process that involves all interested parties (stakeholders) comprising local government officials, local communities, architects, developers, business people, and planners in decision making together. [29] emphasized that with the support and cooperation of various parties, the developments planning will 
be more meaningful and the community marginalization issue would go away. This recommendation is made to allow local communities guidance and support necessary to involve them in the tourism sector. Without these guidance and support it is feared that they can be easily exploited by certain parties who want to profit from the ongoing development of the local community by marginalizing or sidelining them itself from the progress.

The exploitation of rural tourism sector can help in the growth, sustainability and diversification of the rural economy. To meet this goal, entrepreneurship is seen as a major catalyst for the tourism sector, which is believed to be able to boost the economic activities in the rural communities [30]. The active participation of the population in entrepreneurship is deemed necessary and significant in invigorating the economic activities in the lcoal communities. According to [31], the issue of participation of communiy in the field of entrepreneurship should be viewed in the broader context as it has a good potential to be further developed and expanded in the future.

\section{Entrepreneurship as a Catalyst for Rural Tourism Development}

By far there is no one definite definition applicable to the entire term entrepreneur. The meaning attached to the word entrepreneur is growing along with the development of the theory. By definition, entrepreneurs turn out to be someone who was willing to bear the risk of profit and loss as a result of a contract with the government at a fixed price in the 17th century [32]. According to him, entrepreneurs in Malaysia, entrepreneurs may be referred to as those trying to various incentives provided by the government which may include entrepreneurs looking for opportunities in an organization, entrepreneurs seeking their own without the aid of any party and finally the emergence of entrepreneurs through interaction among operators.

Entrepreneurship is one of the strategies in the development of a country, the support element and the development of rural tourism [25]. Thus, it is seen as a catalyst that can overcome the problems associated with economic growth, social inequality and job opportunities [1]. Nearly $99.2 \%$ of the entrepreneurs in Malaysia are Small and Medium Enterprises (SMEs) which accounted for 32\% of Gross Domestic Product (GDP) [33]. In addition, the Ministry of Rural and Regional Development and its agencies have churned 205,081 entrepreneurs under the Ninth Malaysia Plan (9MP). In many developing countries, the number of entrepreneurs in the tourism sector are increasing with the help from the government that strengthen and build the strength of small and medium industries (SMIs) which indirectly reduce the unemployment rate among local communities [2] and contribute to the alleviation of poverty [22].

[34] incorporates a theory of the development of tourism, which is a catalyst for the development of entrepreneurship and small business performance. The development of tourism can provide opportunities for local communities by offering the services or sell products to local and foreign tourists. According to [30], through rural tourism, tourists were taken on visits to the several centers of SMEs business consisting of the production of food products such as chips worked villagers, traditional cakes, shrimp paste, cencaluk, batik products, rattan, wood carving products, marble items and so on. As a result, tourists have the opportunity to buy these products and participate in the producting of these local village produce such as in batik painting and rattan goods production etc with the able assistance from the local community.

The rural communities participating through SMEs such as in making handicrafts, souvenirs, etc. are able to receive orders and favorable market throughout the year. This provide evidence that all the facilities provided by the government to advance the involvement of entrepreneur in rural areas is fruitful. Throughtout the years, the government has provided a variety of support and help to promote the development of SMEs and provide many opportunities for the development of entrepreneurship in local communities. This move were undertaken to drive the economy to achieve the high income status by 2020 .

Many research have been carried out in relation to the contribution of the rural tourism sector through entrepreneurship. A study conducted by [35] found that the development of tourism activities contributes to the existence of various service sectors such as rest homes, hotels, services, other 
handicraft business growth centers or travel agents. As a result of these growth, employment opportunities is opening up to the various levels of society. This directly catalyzes the process of urbanization, the growth of the resort prompted by the local people, an increase of Small and Medium Enterprise (SMEs), increase state income and population, and the development of communication systems and road networks.

The development of tourism for example in Pulau Tioman is successful in involving local community participation in the accommodation, catering (restaurants), tourism support services and so on. However, a study by [36] found that incentives are less help in developing tourism entrepreneurship. This is because there are many entrepreneurs who do not realize the existence of these incentives, in addition to not knowing the requirements to get it. After giving information about it, many entrepreneurs view these incentives are beneficial to them. However recommended that the government provide financial assistance easy to tour operators, particularly in sub-sectors of accommodation and transport that involves so many operators.

[37] explores the issues and challenges faced by the Batek community as a result of tourism development in Kuala Tahan, Pahang. The study found that community involvement in tourism economic activities are divided into two categories which as employees (tour guides and boat drivers) as well as the subject of a tourist attraction in itself (a cultural icon). The women of the Batek community produce handicrafts while men help market their product. Even so, their involvement in the tourism industry is highly dependent on their good relations with the outside community, as well as communication skills while dealing with foreign tourists.

The factors that influence the participation of Bumiputera entrepreneurs in the tourism sector in the Bandar Hilir, Malacca is addressed by [38]. The study found that most respondents are those who want to succeed in entrepreneurship. They are also the most forward-looking and confidence. The spirit can help them be successful in the field of tourism entrepreneurs, but it is often restricted by the lack of support from family members. Problems faced by the respondents include difficulty in obtaining capital as well as extensive competition from other entrepreneurs. This problem is a major obstacle to the development of Bumiputera entrepreneurs in the Bandar Hilir, Malacca.

[13] describe the level of participation of the population and explain the factors that influence the level of community participation in the study of the Kubang Pasu District, Kedah. The findings shows that the level of participation of the community in the field of entrepreneurship in the study area is moderate. Among the factors that influence the level of local communities participation include capital or finance and training. Most importantly, the findings also showed that cronyism and political relations also have a significant impact in influencing the level of participation of the population in the study area.

[39] discuss the potential of women as household heads in rural areas or known as single mothers to become entrepreneur as a way to get out of poverty. This is in line with effort made bythe Minister of Women, Family and Community Development, to urge women to venture into business. In addition, the ministry is also working with non-governmental organizations in implementing programs to increase women's skills in particular areas of entrepreneurship so that they can be independent and become increasingly competitive in the future. Nowadays, many schemes have been trained, being assisted especially the single mothers. However, the challenges are great and many of them failed to succeed without the government assistance. Due to this problem, there are many single mothers in rural areas who were below the poverty line.

[33] identifies factors driving the transformation of Malay entrepreneurs in Johor Bahru.This study analyzes the performance and the factors that affect it. The results generally shows that the individual initiatives, family and religious motivation are key factors that drives them to venture into entrepreneurship while their background factors, business management skills, networking skills and institutional or government support are significant factors affecting their business performance. The study found that there are four important factors that influence the performance of Malay entrepreneurs and SMEs in Johor Bahru namely background factor, management skills, business skills and support networks or government institutions.

The government remains committed to explore the potential of SMEs, including in rural areas in order to create successful entrepreneurs at the national, regional and global levels. Among the 
strategies proposed, including the development of SMEs as the engine of growth and innovation by reducing regulatory costs incurred by the SME, SME capacity building, support the creation of a culture of entrepreneurship, strengthening and enhancing access to financing [4]. [40] noted not only the policy, but also personal skills, motivation and initiative is important to start a new business. Entrepreneurship policies appropriate to create a conductive environment and provide a comfortable environment for other potential entrepreneurs who want to start a new business.

\section{Conclusion}

It is believes that entrepreneurship is a key catalyst in the economic sphere in rural areas. Naturally entrepreneurship is developed towards the further prosperity of the economic potential of rural areas. To realize this goal, all the good among the villagers, the entrepreneurs nor the agencies concerned should cooperate and work together to strengthen and further develop rural entrepreneurship. For this purpose, the rural population should be aware and have their own initiatives towards enhancing their economies. There are various incentives and support such as access to capital, opportunities to attend courses and entrepreneurial training, marketing aspects of a broader and deeper exposure to entrepreneurship should be assisted to cultivate interest and inclination to participate in entrepreneurship. In addition, each rural development agency should play a more effective and efficient in helping and encouraging the participation of communities and further developing entrepreneurship in rural areas. It is hoped that the close cooperation established between population and development agencies will be able to strengthen and highlight the potential of entrepreneurship in rural areas. The main role of the Ministry of Rural and Regional Development is to provide exposure and knowledge of the rural tourism sector in order to make rural areas attractive as a tourist destination, to provide knowledge and skills to become entrepreneurs in the field of rural tourism, provide exposure and knowledge of rural tourism as an activity which can give additional sources of income for rural communities and provide exposure, knowledge and skills that can promote environmental beautification and preservation of cultural beauty of the countryside. Ministry of Rural and Regional Development has always placed a priority to integrate rural development strategy with programs that increase income and quality of life. Efforts still need to be improved to ensure that the poverty rate in rural areas is not only reduced, but is able to achieve the targeted level of income by the government in 2020 .

\section{Acknowledgments}

The authors would like to thank the Ministry of Higher Education for the fund provided through STRC for this research.

\section{References}

1. Taskov, Nako and Metodijeski, Dejan and Dzaleva, Tatjana and Filiposki, Oliver. Entrepreneurship in Tourism Industry Lead to Business Benefits, 2nd Biennial International Scientific Congress 27-29 April, 2011, Skopje, Macedonia, (2011)

2. P.Sheldon, \& T. Var. Resident Attitudes To Tourism In North Wales, Tourism Management, 5 , 1, 40-48, (1984)

3. E. Tatoglu, F. Erdal, H. Ozgur \& S. Azakli. Resident Perception Of The Impacts Of Tourism In a Turkish Resort Town. Retrieved http://www.opf.slu.cz/vvr/akce/turecko/pdf/Tatoglu.pdf, (Mei 15 Mei 2014), (2000)

4. Pelan Induk Perancangan Luar Bandar. Portal Rasmi Kementerian Kemajuan Luar Bandar dan Wilayah. http://www.rurallink.gov.my/pelan-induk-pembangunan-luar-bandar-piplb- (2014)

5. Y. Yusnita, M.M Shaladdin, W.A Aziz . Rural Tourism in Malaysia: A Homestay Program, China-USA Business Review, 12, 3, 300-306, (2013) 
6. R. Merican Abdul Rahim Merican, M. Ruzian and A. Azrol. Homestay Industries: Surviving the Legal Challenges, Pertanika Journal of Social Sciences \& Humanities, 22, 309-328, (2014)

7. A. Milman \& A. Pizam. Social Impacts of Tourism on Central Florida, Annals of Tourism Research, 15, 2, 191-204, (1988)

8. A. Rosniza, A. Mustaqim, A. Rahim, Rosmiza, Novel Lyndon and Mohd Azlan. Persepsi PelancongTerhadap Agensi Pelancongan Di Langkawi Geopark. Journal of Society and Space,

8, 7, 147-154, (2012)

9. D. Getz \& J. Carlsen. Characteristics and Goals of Family and Owner-Operated Businesses in The Rural Tourism and Hospitality Sectors. Tourism Management, 21, 547-560, (2000)

10. A. Talib \& H. Jusoh, Penyertaan Komuniti dalam Bidang Keusahawanan Luar Bandar. Kajian di Daerah Kubang Pasu, Kedah, Prosiding PERKEM VII, JILID 2, 738-749, (2012)

11. H. Fatimah \& B. Nurwati. "Pembangunan Luar Bandar: Ke Arah Peningkatan Produktiviti dan Kepelbagaian Asas Ekonomi" dalam Pembangunan Wilayah dan Alam Sekitar: Cabaran dalam Merealisasikan Rancangan Malaysia Kesembilan, diselenggara oleh Asan Ali Golam Hassan. Sintok: Penerbit Universiti Utara Malaysia, 79-92, (2008)

12. A. Liu. Tourism in rural areas: Kedah, Malaysia, Tourism Management, 27, 5, 878-889, (2006)

13. F.J. Blancas, M. L. Oyola, M. González, F.M. Guerrero, \& R. Caballero. How To Use

Sustainability Indicators for Tourism Planning: The Case of Rural Tourism in Andalusia (Spain). Science of The Total Environment, 412, 413, 28-45, (2011)

14. J. Briedenhann \& E. Wickens. Tourism Routes As a Tool For The Economic Development Of Rural Areas-Vibrant Hope or Impossible Dream? Tourism Management, 25, 71-79, (2004)

15. K. Kalsom \& N.M. Ashikin. Penglibatan Ahli Komuniti Dalam Program Pembangunan Komuniti: Program Homestay Di Kedah. Akademika, 67, 77-102, (2006)

16. C. Tosun. Limits to community participation in the tourism development process in developing countries. Tourism Management, 21, 1, 613-633, (2000)

17. J. Brohman. New Directions in Tourism for Third World Development, Annals of Tourism Research, 23, 1, 48-70, (1996)

18. T. Cengiz, F. Ozkok, \& C.K. Ayhan. Participation of the local community in the tourism development of Imbros (Gokceada), African Journal of Agricultural Research, 6, 16, 38323840, (2011)

19. K. Lindberg, J. Enriquez, \& K. Sproule, K.. Ecotourism questioned: Case studies from Belize. Annals of tourism Research, 23,3, 543-562, (1996)

20. N.Y. Hafizah \& A.A. Rahimah. Kelestarian Langkawi Geopark: Penglibatan Komuniti Kuala Teriang, Langkawi. Akademika, 78, 95-101, (2010)

21. M. Akunaay, F. Nelson. \& E. Singleton. Community Based Tourism in Tanzania: Potential and Perils in Practice, Second Peace through Tourism Conference, Tanzania (2003)

22. J.W. Ashe. Tourism investment as a tool for development and poverty reduction. The experience in Small Island Developing States (SIDS). [Online] http://www.tanzaniagateway.org/docs/tourism_investment_as_a_tool_for_development_and_p overty\%20reduction.pdf, (February 16, 2014), (2005)

23. A. Norzaini, A.H. Sharina, L. O. Puay \& K. Ibrahim. The Langkawi Global Geopark: Local community's perspectives on public education, International Journal of Heritage Studies, 17, 3, 261-279, (2011)

24. S. Akis, N. Peristianis \& J. Warner,. Residents' attitudes to tourism development: the case of Cyprus, Tourism Management, 17, 7, 481-494 (1996)

25. C.Surugiu. Development of Rural Tourism Through Entrepreneurship, Journal of Tourism, 8, 65-72, (2009)

26. F. Aref, S.S. Gill \& F. Aref. Tourism Development in Local Communities: As a Community Development Approach. Journal of American Science, 6, 2, 155-161, (2010)

27. M. Chapman \& K. Kirk. (Julai 2001). Lessons for Community Capacity Building: A Summary of The Research Evidence. School of Planning and Housing Edinburgh College of Art/Heriot-Watt University. Research Department, Scottish Homes. Retrieved at 23 Mei 2014, dari laman sesawang: http://docs.scie-socialcareonline.org.uk/fulltext/scothomes30.pdf (2011) 
28. D.J. Timothy. Participatory Planning: A View of Tourism In Indonesia. Annals of Tourism Research, 26, 2, 371-391, (1999)

29. I. Yahaya. Komuniti Pulau dalam Era Pembangunan: Terpinggir atau Meminggir? Akademika, 70, 57-76 (2007)

30. I.A. Johan \& A.M. Zaki. Program Homestay Pemangkin Pertumbuhan Ekonomi Luar Bandar, Kajian Kes: Negeri-Negeri Utara Semenanjung Malaysia, Prosiding PERKEM IV, Jilid 2, $227-$ $242(2009)$

31. T. Azlizan, J. Hamzah, I. Yahaya \& A. Habibah. Penyertaan komuniti dalam bidang keusahawanan luar bandar, Malaysia Journal of Society and Space, 8, 9, 84-96, (2012)

32. A.L. Mohd Abdullah Jusoh, Y. M. Azlan, J. Osman, Syahira Hamidon., 2012, Asas Keusahawanan dan Pengurusan Perniagaan Kecil dan Sederhana, Universiti Malaysia Kelantan: Kelantan.

33. A.G.M. Asri \& D. Zaimah. Transformasi dan Prestasi Perniagaan Usahawan Melayu Perusahaan Kecil dan Sederhana (PKS) di Johor Bahru. Prosiding PERKEM VII, JILID 1, 696-708 (2012)

34. O. Pazim \& M. Rosli. The Impact of Tourism on Small Business Performance: Empirical Evidence from Malaysian Islands, International Journal of Business and Social Science, 2, 1, 11-21, (2011)

35. K.T. Lee \& O.S. Suriani. Pertumbuhan dan Pelestarian Industri Eko-Pelancongan: Kajian Pulau pulau Peranginan Sekitar Pantai Timur Sabah, Sosiohumanika, 3, 2, 273-294 (2010)

36. N.H.M. Salleh, R. Othman, S.H.M. Idris. Penglibatan Komuniti Pulau Tioman dalam Bidang Keusahawanan Pelancong dan Peranan Insentif Pelancongan, Journal of Tropical Marine Ecosystem, 2, 2, 57-71, (2012)

37. M. Zanisah, Z.N. Fatanah \& O. Mustaffa. Kesan Ekonomi Pelancongan Terhadap Komuniti Batek Di Kuala Tahan, Pahang, Journal e-BANGI, 4, 1, 1-12, (2009)

38. H. Shahrin and L.K. Goh. Penglibatan Usahawan Bumiputera dalam Sektor Pelancongan: Satu Kajian Kes Di Kawasan Bandar Hilir, Melaka. Universiti Teknologi Malaysia Institutional Repository, [online] http://www.fp.utm.my/ePusatSumber/pdffail/ptkghdfwP2/p_2009_9183_5c99079fdf3342b391 38ec251cbb0832.pdf (2010)

39. Roddin, Rohayu and I. Mukhtar, Marina and Esa, Ahmad and Warman, Sarebah and Mohamed, Maziana and Mohamed Yusof, Anizam and Ab Rahman, Azmanirah. Pendidikan kemahiran keusahawanan dalam kalangan wanita ketua isi rumah luar bandar, Seminar Majlis Dekan Pendidikan IPTA, 2-3 Ogos 2010, Shah Alam, (2010)

40. M. Lordkipanidze, H. Han Brezet \& M. Mikael Backman. The Entrepreneurship Factor in Sustainable Tourism Development, Journal of Cleaner Production, 13, 8, 787-798 (2005) 